\title{
The Pilot of La Salle's Griffon
}

\section{Joe Calnan}

L'explorateur français Robert Cavelier de La Salle (1643-1687) avait un petit caboteur à voile gréé en barque construit en 1679 pour voyager entre la rivière Niagara et le lac Michigan. La Salle a embauché un pilote qualifié et expérimenté pour mener le navire sur ces eaux, mais en moins de neuf mois suivant le début de son emploi sur les Grands Lacs, le pilote avait perdu deux barques qui lui ont été confiées et a disparu avec l'équipage entier. La perte du Griffon de La Salle a été chroniqué par le missionnaire récollet Louis Hennepin, et est devenu l'un des grands mystères des Grands Lacs. Aujourd'hui, le pilote a acquis une notoriété comme un grand hérétique danois, de mauvaise humeur, grand de sept pieds, nommé Luke Dare; mais si ce personnage a son fondement dans les sources primaires ou dans le folklore n'a jamais été clairement établi. En examinant systématiquement les origines de l'information que nous avons sur le pilote dans les documents autant primaires que secondaires, le présent article tente de séparer le folklore des sources vérifiables et mettre en lumière une image plus précise du pilote $d u$ Griffon de La Salle.

At the ship's helm was an odd sort of character. Standing seven feet tall, Luke the Dane was known for his violent temper and an attitude that spoke "does not work well with others." Yet he was a good pilot and was needed if the Griffon was to be a success. ${ }^{1}$

We saw near the village of Matchinkoa a tree from which the bark had been removed three or four years ago, and on which was depicted a man with a tapabord hat pulled down below his ears, a grey justaucorps, breeches, short legs, a big beard, and a gun in his hand, another figure near him, tied up like a slave, and four scalps. ${ }^{2}$

When Robert Cavelier, Sieur de La Salle was given permission by Louis XIV to

1 Colleen Burcar, It Happened in Michigan: Remarkable Events That Shaped History (Guilford, 2010), 8.

2 Lettre de La Salle au Gouverneur La Barre, 4 Juin 1683 in Pauline Dubé, La Nouvelle France sous Joseph-Antoine Le Febvre de La Barre 1682-1685 (Québec,1993), 73-80; author's translation. This document also appears in Pierre Margry, ed., Découvertes et Etablissements des Français dans l'Ouest et dans le Sud de l'Amérique Septentrionale, 6 vols. (Paris, 1876-1888), II: 325. Original Document: Archives nationales de France (AN), Archives Coloniales, C13C, vol. 3, f. 44-47.

The Northern Mariner/le marin du nord, XXIII No. 3, (July 2013), 213-238 
explore the Mississippi to its mouth and build forts wherever he considered it necessary, he determined to use small cargo vessels called barques to transport his men and supplies through Lakes Erie, Huron and Michigan, and down the Illinois and Mississippi River to the Gulf of Mexico. La Salle, as the seigneur of Cataraqui (Kingston, Ontario) had already been using barques for transport on Lake Ontario and the upper Saint Lawrence River since 1676. Under the guidance of Louis Fontaine, the reliable pilot of his barque on Lake Ontario, ${ }^{3}$ La Salle had realized a considerable cost savings by using barques rather than canoes for transporting freight wherever possible. Transport on the Great Lakes by barque offered the economy of carrying a larger cargo with fewer men, and a secure place to sleep at night when abroad in unsafe territory. The system had worked well, but all that changed when La Salle hired a new pilot to guide the barque that he intended to build for the lakes above Niagara Falls.

La Salle brought a pilot known as Luc, or Lucas, to the Great Lakes with him in late 1678. He had apparently sailed on the largest vessels trading to Canada and the Caribbean Islands, and was a highly experienced and skilled pilot. However, from his very first voyage in La Salle's employ, the pilot showed a determination to destroy the vessels that were entrusted to his care. The brief time of the pilot's career on the Great Lakes was marked by disasters and near disasters that cost La Salle two barques, astronomical financial losses, and nearly his life and the lives of his men.

On 18 September 1679, less than nine months after the pilot's arrival on the Great Lakes, the 45-ton barque Griffon sailed from Washington Island, Wisconsin into Lake Michigan with a cargo of valuable furs destined for La Salle's storehouse on the Niagara River. On board were the pilot, five sailors, and a "supercargo," a man employed to be responsible for the safekeeping of the vessel's cargo. A storm arose the following night which lasted for several days; the Griffon was lost and none of the men on board were ever seen alive again. Or were they? Two documents written by La Salle that have received very little attention from Great Lakes maritime historians tell that a man matching the pilot's description was captured by Natives on the upper Mississippi. While often referred to, the actual content of the letters has thus far remained obscure.

The pilot of the Griffon has become a legendary figure in the centuries since this first-ever sailing voyage on the upper Great Lakes. The mystery surrounding the disappearance of the vessel and its crew has tantalized people for over three hundred years. Over a dozen wrecks have been claimed to be the remains of the Griffon, but none has ever been proven. With each discovery of a new Griffon wreck, the popular mythology grows a little more and folklore is intermixed with the verifiable evidence. Today, contemporary writers tell us that the pilot of La Salle's Griffon was a seven-foottall fiery-tempered heretic from Denmark named Luke Dare or Luc the Dane. Whether

3 A pilot, in the context of this paper is a person whose trade is the guiding of a vessel; trained in the algebra and trigonometry of navigation using reference points obtained from the compass, the sounding lead, the speed log and visible points on land. A pilot is distinct from a captain, whose title is derived from military ranks and indicates a position of supremacy over underlings. The term captain does not appear in the primary sources concerning La Salle's vessels on the Great Lakes. 
this persona can be verified by primary evidence is the question that drives the research presented here. This paper will seek to define the identity of the pilot as clearly as possible with the primary sources that are known to exist. Descriptions of the pilot that have appeared in English will be discussed and then compared against the original French sources in the hope of setting a rather confusing record straight.

\section{Hennepin: the first source in English}

For almost two hundred years after the voyage of the Griffon, the sole source of information on the topic available to English readers was Father Louis Hennepin's A New Discovery of a Vast Country in America, published in London in 1698. Hennepin had been a missionary attached to La Salle's expeditions and had been present for both the construction and the voyage of the Griffon. Unfortunately, Hennepin's writing was aimed at the thriving and lucrative European market for stories of exploration and adventure which existed at that time and he was not one to let facts get in the way of a good tale. Hennepin had published a concise account of his adventures titled Déscription de la Louisiane in 1683 when he first returned from New France. It had sold extremely well and been reprinted many times in Italian, Dutch and German translations. After La Salle's death in 1687, Hennepin wrote a greatly expanded version which borrowed material from other authors. This new revision included his infamous claim that he himself had secretly discovered the mouth of the Mississippi before La Salle did. It is this version which was published in 1698 as the first English translation of Hennepin's work to appear.

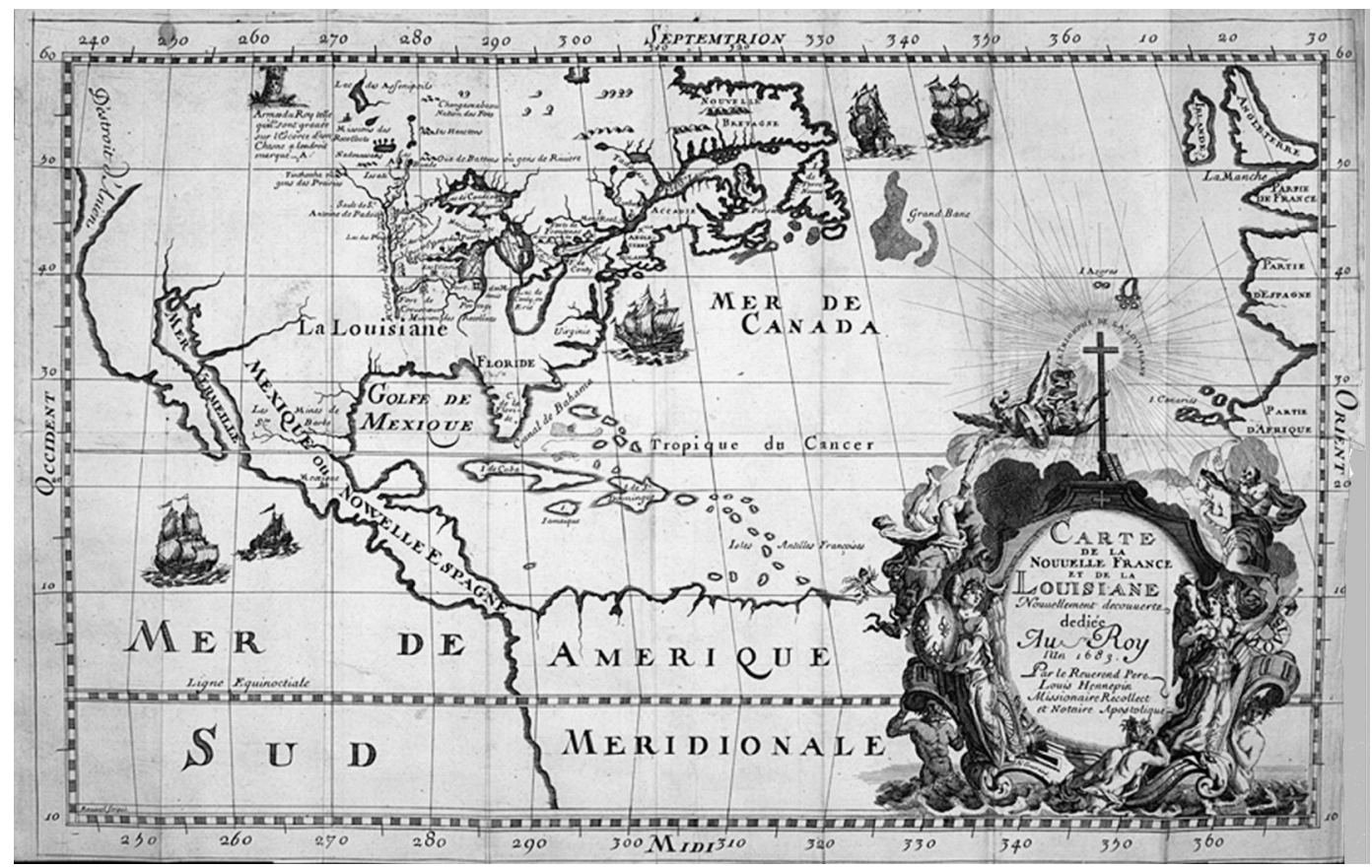

Illustration 1: "Carte de la Nouvelle France et de la Louisiane Nouvellement decouvertes ... 1683 ... par le Reverend Pere Louis Hennepin."

Courtesy Naval Marine Archive. 
While Hennepin cannot be considered absolutely reliable unless corroborated by other sources, he was actually there taking notes at the time these events occurred and is a valuable primary source. He gives an eyewitness account of sailing on the boat from Niagara to Lake Michigan and makes several observations of the pilot which have become the foundation of all that has since been written about him.

Hennepin mentions the pilot several times in his 1698 New Discovery of a Vast Country in America. The first is in his description of the loss of one of La Salle's barques on Lake Ontario, on 8 January 1679:

On the $20^{\text {th }}$ arrived M. de la Salle from Fort Frontenac, from whence he was sent with a great Barque to supply us with Provisions, Rigging, and Tackling for the Ship we design'd to build at the mouth of Lake Erie; but that Barque was unfortunately cast away on the Southern Coast of the Lake Ontario, by the fault of two Pilots, who could not agree about the Course they were to steer, tho' they were then only within two Leagues of Niagara. ${ }^{4}$

After the construction of the Griffon was complete, it was necessary to bring it up the Niagara River to Lake Erie. Strong currents heading toward Niagara Falls made this very risky. Of July 1679 Hennepin writes: "Having forbid the Pilot to attempt to sail up the Currents of the Streight till farther order, we return'd the $16^{\text {th }}$ and $17^{\text {th }}$ to the Lake Ontario, and brought up our Bark to the great Rock of Niagara, and anchor'd at the foot of the three Mountains..." 5

In August of 1679, La Salle came to personally supervise the hauling of the Griffon up the Niagara River to Lake Erie. Hennepin commented that: "The stream is so violent, that our Pilot himself despair'd of Success." 6

After passing Lake Erie and the St. Clair River, the voyage continued across Lake Huron, where: "We sounded all Night long, because our Pilot, though a very understanding Man, was somewhat negligent."

On the voyage through Lake Huron, a violent storm arose. This passage is the origin of the pilot's current reputation as an ill-tempered godless heretic:

M. de la Salle, notwithstanding he was a Courageous Man, began to fear, and told us we were undone; and therefore every body fell upon his Knees to say his Prayers, and prepare himself for Death, except our Pilot, whom we could never oblige to pray; and he did nothing all that while but curse and swear against M. de la Salle, who, as he said, had brought him thither to make him perish in a nasty Lake, and lose the Glory he had acquir'd by his long and happy Navigations on the Ocean.

Hennepin's description of the departure of the Griffon from the Island of the Pottawatomies (Washington Island in what is now Wisconsin's Door County) and its subsequent loss, gives the reader one final snippet of insight into the character of the pilot:

4 Louis Hennepin, A New Discovery of a Vast Country in America, Reuben Gold Thwaites, ed. (Chicago, 1903), 89.

5 Hennepin (1903), 103.

6 Ibid., 107. 
M. de la Salle, without asking any body's advice, resolv'd to send back his Ship to Niagara, laden with Furrs and Skins to discharge his Debts; our Pilot and five Men with him were therefore sent back, and order'd to return with all imaginable speed, to join us toward the Southern Parts of the Lake, where we should stay for them among the Illinois. They sailed the $18^{\text {th }}$ of September with a Westerly Wind, and fir'd a Gun to take their leave. Tho' the Wind was favourable, it was never known what Course they steer'd, nor how they perish'd; for after all the Enquiries we have been able to make, we could never learn any thing else but the following Particulars.

The Ship came to an Anchor to the North of the Lake of the Illinois, where she was seen by some Savages, who told us that they advised our Men to sail along the Coast, and not towards the middle of the Lake, because of the Sands that make the Navigation dangerous when there is any high Wind. Our Pilot, as I said before, was dissatisfy'd, and would steer as he pleas'd, without hearkining to the Advice of the Savages, who, generally speaking, have more Sense than the Europeans think at first; but the Ship was hardly a league from the Coast, when it was toss'd up by a violent Storm in such a manner, that our Men were never heard of since; and it is suppos'd that the Ship struck upon a Sand, and was there bury'd. ${ }^{7}$

Hennepin's final reference to the pilot sees La Salle's party preparing to leave the Lake Michigan shore and head toward the Illinois River in November 1679: "We mark'd the way from Place to Place with some Trees for the convenience of those we expected after us; and left at the Portage, as well as Fort Miamis, Letters hanging down from the Trees, containing M. de la Salle's Instructions to our Pilot, and the other five and twenty Men who were to come with him." 8

In summary, Hennepin's 1698 book gives us precious little about La Salle's pilot - no name, no physical description, no nationality; only that two vessels were wrecked while in his charge, he wouldn't pray, he would not take advice from native people, and he claimed to have been a respected ocean mariner prior to his employment with La Salle. For almost two hundred years after the event, this was the only information available in English about La Salle's pilot.

\section{Luc or Luke}

Skip forward two hundred years. The Great Lakes are a thriving corridor of commerce and industry. A small wave of interest in La Salle's explorations began with the 1852 publication of a biography of the explorer by Harvard University president Jared Sparks. Sparks continued to collect documents for an expanded biography of La Salle, but died before the project was completed. When Sparks died, the documents passed to Harvard alumnus Francis Parkman, who took on writing the expanded biography as part of his France and England in North America series. Parkman's biography of La Salle, The Discovery of the Great West, appeared in 1869 and sold extremely well. By 1878 it was already in its $10^{\text {th }}$ edition. ${ }^{9}$ 
The $200^{\text {th }}$ anniversary of the voyage in 1879 saw a flood of interest in La Salle and his Griffon. The United States Congress funded the publication of transcriptions of original documents relative to La Salle's enterprises that were collected by French archivist Pierre Margry; a bicentennial commemoration of the Griffon was held in Grosse Pointe, Michigan with addresses by distinguished speakers; and a steady stream of publications hit the presses. Francis Parkman revised his biography and re-titled the work La Salle and the Discovery of the Great West.

Regarding the pilot of the Griffon, Parkman largely reiterates the information given by Hennepin's New Discovery while adding a few new details: Parkman tells us that days before La Salle's barque was wrecked on the south shore of Lake Ontario, the pilot came close to wrecking it on the north shore. ${ }^{10}$ Later, we are told that La Salle had originally planned to send Tonty in charge of his men on the Griffon, but changed his plans and sailed on the ship himself because he suspected that the pilot was in the pay of his enemies. The third and most intriguing piece of information contributed by Parkman is in a footnote concerning a letter written by La Salle to the governor of New France in 1683. In the letter: 'La Salle expresses his belief that his vessel, the 'Griffin,' had been destroyed, not by Indians, but by the pilot, who, as he thinks, had been induced to sink her, and then, with some of the crew, attempted to join Du Lhut with their plunder, but were captured by Indians on the Mississippi." $" 11$

In addition to Hennepin, Parkman's work has been a principal source for every subsequent writer on the Griffon. Parkman, however, never mentions a name or a description of the pilot. His intriguing footnote has been paraphrased countless times, but in the 140 years since it appeared in print, the original letter to which it refers has apparently never been consulted by writers of Great Lakes history.

The first writer in English to use the name Luc for the pilot was Orasmus H. Marshall of the Buffalo Historical Society. In 1863, Marshall read a paper titled "The Building and Voyage of the Griffon" before the society. The paper was revised by the author and published by the society in 1879 for the $200^{\text {th }}$ anniversary of the voyage. Marshall writes: "She was placed under the command of the pilot, Luc, assisted by a supercargo and five good sailors; with directions to call at Missilimackinac, and from thence proceed to the Niagara." 12

The source for Marshall's name for the pilot was made available in English the following year when a translation of Hennepin's original book, Description de la Louisiane, was published by John Gilmary Shea. Hennepin's 1683 work states: "De plus on avoit envoyé deux de nos hommes à Missilimakinac, instruits de toutes choses pour servir de guide au Pilote Luc." ${ }^{13}$

to the first and eleventh editions.

10 Parkman (1879), 128.

11 Parkman (1879), 301.

12 Orasmus H. Marshall, The Building and Voyage of the Griffon in 1679 (Buffalo, 1879), 287.

13 Louis Hennepin, Description de la Louisiane, Nouvellement Découverte au Sud'Oüest de la Nouvelle France, par ordre du roy. Avec la carte du pays: les mours \& la manière de vivre 
John Gilmary Shea translated this passage using an anglicised spelling of the name Luc: "We had moreover sent to Missilimakinac two of our men, informed of all things to serve as guides to Luke the pilot." 14

In 1899, a Chicago publishing house issued a comprehensive two-volume work entitled History of the Great Lakes Illustrated. Volume 1 was edited by J.B. Mansfield and contains a detailed account of the voyage of the Griffon. Mansfield used Parkman and O.H. Marshall for his sources, lifting the following passage from Marshall word for word: "She was placed under the command of the pilot, Luc, assisted by a supercargo and five good sailors, with directions to call at Michilimackinac, and from thence proceed to the Niagara." 15

History of the Great Lakes Illustrated became the standard reference on the subject for the following two generations, and we see "Pilot Luc" repeated by countless later authors, including Frank Severance, whose 1917 An Old Frontier of France was very widely read and cited.

Other authors of later years chose to follow John Gilmary Shea's spelling of "Luke," which was used by Frances Gaither in her 1931 biography of La Salle, The Fatal River, and subsequently used by Canadian marine historian C.H.J. Snider.

\section{Lucas}

In 1891, Cyrus Kingsbury Remington, another Buffalo historian, published a book called The Ship-Yard of the Griffon. While it does not mention the pilot, Remington's book calls attention to an edition of Hennepin's work titled Voyage ou Nouvelle Decouverte D'un Tres-Grand Pays dans L'Amerique. This edition, published in Amsterdam in 1704, is the first to feature the now famous illustration of the Griffon under construction beneath a palm tree. The illustration is not the only addition to this 1704 edition. In describing the passage between lakes Erie and Huron, Hennepin tells us that the pilot, named Lucas, measured the diameter and the shape of the lake in the middle of the strait, and that the travellers named it Lac Sainte Claire: "Dans le milieu ce Détroit s'élargit par un Lac plus petit que les autres, \& qui est d'une figure circulaire de six lieuës de diametre, selon l'observation de notre Pilote, nommé Lucas. Nous donnames le nom de Sainte Claire à ce Lac." 16

Later in the narrative, Hennepin also uses "Pilote Luc," as in the 1683 book, indicating that the pilot went by both Luc and Lucas.

The first to make use of the name Lucas in English appears to be Charles Moore in his 1915 History of Michigan. Moore tells us: "Crossing the twenty miles of lake, Pilot Lucas saw before him vast stretches of rushes, among which the waters from the river above sought the lake through many a winding channel. After sounding one passage

des sauvages. (A Paris : Chez la veuve Sebastien Huré, 1683), 110.

14 Louis Hennepin, A Description of Louisiana, John Gilmary Shea, ed. (New York, 1880), 133.

15 J.B. Mansfield, History of the Great Lakes illustrated (Chicago, 1899), I: 88.

16 Louis Hennepin, Voyage ou Nouvelle Decouverte D'un Tres-Grand Pays dans L'Amerique (Amsterdam, 1704), 50. Another edition of this book is surtitled "Voyage Curieux." 
after another sufficient depth of water was found and the Griffon pursued her course up the St. Clair River." 17

\section{The Giant}

In 1927, Harry G. Tucker, a lawyer from Owen Sound, Ontario, announced that he knew the location of what he believed to be the wreck of the Griffon on a rough stretch of shoreline at the western end of Manitoulin Island, about a mile north of the Mississagi Straits lighthouse. Tucker, who had last seen this wreck fifty years earlier, led an expedition to investigate it in October 1927, bringing with him two newspaper reporters, Fred Baker from the Toronto Telegram and Mark Dulmage from the Owen Sound Sun Times. J. Virtue of the Ontario Department of Education was also on the expedition. At the time, the Department of Education conducted archaeological investigations and published the annual Ontario Archaeological Report.

The expedition was followed closely by the Owen Sound and Toronto newspapers, and was carried in the Christian Science Monitor and New York Times as well. The men set off by steamer on 17 October in search of a shipwreck with copper caulking in the plank seams. A newspaper article that announced the departure of the expedition reads: "Copper Caulking Means Positive Identification - Should Mr. H.G. Tucker and his party be successful in locating the wreck of the long lost schooner Griffin, one of the first ships to sail the Great Lakes, there is a very positive means of identification. Accurate historical data shows that the vessel's seams were caulked with copper." $" 18$

This article typifies the deluge of confused information that was about to begin. Schooners had yet to appear in North America when the Griffon was built, and the idea of caulking a ship's seams with copper is completely without basis in "historical data." When the party reached the site of the wreck, the conclusion of Fred Baker and Mark Dulmage was quick and decisive: huge headlines on the Owen Sound newspaper announced "DOUBT VERY MUCH IF WRECK IS LA GRIFFON"19 and indicated that the few fragments that remained of the wreck indicated a vessel many times the size of the Griffon, and of comparatively recent construction. There were no planks left, and no caulking, copper or otherwise; just a section of massive twin keelsons of mill-sawn lumber attached to enormous sawn floor timbers with an abundance of three-foot long, threaded, inch-thick bolts. All available evidence precluded the possibility of the wreck being the Griffon. Fred Baker of the Toronto Telegram wrote that:

Admiral Bayfield, while serving as a lieutenant in the navy in 1813, made mention in his report to the government of an ancient wreck on the bluffs. Charts issued in 1822 as a result of Admiral Bayfield's survey indicate the presence of a wreck. Such a wreck, however, must long since have been pounded to atoms by the fifty-foot ice jams that each winter cover the shore on which she was supposed to lie. The

17 Charles Moore, History of Michigan (Chicago, 1915), 83.

18 Owen Sound Daily Sun Times (Hereafter DST), 19 October 1927.

19 DST, 21 October 1927. 
shattered timbers now on the site do not seem to have any possible connection with the Griffon. The theory is advanced, but secures little support that the wreck in question may be a British or American ship which came to grief in the war of 1812 . There is no evidence to suggest the supposition, and in fact there is no indication that the remaining timbers are even that old. ${ }^{20}$

The articles mention several skeletons which had been found in nearby caves forty years earlier, all of which had been identified as Natives at the time and were accompanied by birch bark wrappings. Of the copper caulking, the Sun Times reported: "Quite a number of the citizens of Manitoulin Island, particularly those who live in the vicinity of Gore Bay, recall having been told by their relatives of this wreck on the west shore, and of being told that the decks were caulked with copper wedges, but none will admit having seen such things themselves." ${ }^{21}$ Fred Baker wryly summed up the findings of the investigation this way: "While naturally conclusive proof is lacking, a large dose of island legend, plus the statement of those who claim to have seen a very ancient wreck, make a very interesting if not historically sound theory." 22

Despite the overwhelming evidence against the wreck being La Salle's, Tucker remained unconvinced. When his guests on the expedition returned home, Tucker stayed at the site to gather more evidence. Tucker wanted to meet with the keeper of the Mississagi Straits lighthouse, William Albert Grant, who had been away on Cockburn Island when the party arrived. After meeting with Grant, Tucker returned to Owen Sound, where the newspaper reported:

Mr. Tucker, while on Manitoulin Island last week, interviewed a number of people who have been residents there a long time, and elicited considerable information and secured a number of facts which he claims are worthy of much consideration before he will be convinced that the wreck is not that of the Griffon, and he is not going to abandon his belief or lose faith in his ability to prove his contentions. ${ }^{23}$

The information secured by Tucker is revealed in a letter that he wrote to the Sun Times shortly after:

I have received a box of the bolts and nuts taken from the wreck by the father, Mr. Wm. A. Grant, the Lighthouse Keeper, and which I am handing you for public inspection... I hope next spring to be able to obtain the skull of the giant which was found on the shore not far from the wreck in one of the caves, I believe. Luc, La Salle's pilot, who was said to have sailed the Seven Seas, was a giant some seven feet in height with an enormous head. Now the skull which I refer to was almost twice that in size of an ordinary man. I have the ram[m]er which was also found at the wreck and which would appear to have been used for driving home a charge in a mortar or a stationary arquebuse. This would indicate that the wreck was that of an armed vessel. ${ }^{24}$

20 DST, 22 October 1927: "Telegram tells of close search for Griffin hull."

21 DST, 24 October 1927: "H.G Tucker to continue efforts to establish shipwreck's identity."

22 DST, 22 October 1927.

23 DST, 24 October 1927.

24 DST, 19 November 1927: "Hope to Find Skull of Giant Mate of Griffon." The spelling is 
Thus begins the legend of the giant pilot with the giant skull. No source is given for the revelation of the pilot's enormous height. W. A. Grant's eldest son, William Kinzie Grant later recalled in an interview that he last saw this skull when he was three or four years of age, at least fifteen years prior to Tucker's visit. ${ }^{25}$ Tucker made one more trip to visit the wreck site in 1928. He didn't locate a giant skull while he was there, but he did manage to gather more evidence of similar questionable accuracy:

Mr. Tucker was talking with a friend of John Francis, a well known western Manitoulin Island Indian. John Francis, who was about 90 years old when he died, had never seen the wreck himself. But his father had seen it when he was a young boy and the father was about 90 years old when he died. The wreck was an old one when the father of John Francis first saw it. This evidence has confirmed Mr. Tucker's belief that the ship really is of great historical importance and that it actually is the wreck of La Salle's Griffon.

John Francis had died ten years prior to the conversation described above. ${ }^{26}$ Subsequent writers have overlooked this detail while making extensive use of John Francis' "testimony" to support the contention that the Mississagi Strait wreck is the Griffon, but as this first writing of the story reveals, it is far from verifiable.

\section{The Dane}

Harry G. Tucker died in January 1929 and his quest was taken up by an art teacher from the Ottawa Normal School named Roy F. Fleming. Fleming had grown up in Kilsyth, just outside Owen Sound. His uncle and cousin owned Fleming Publishing Company and the Owen Sound Sun Times newspaper. Roy Fleming had been a school teacher on Manitoulin Island some time at the turn of the century and had relatives there.

In the $250^{\text {th }}$ anniversary year of the Griffon's voyage, Fleming published an article in The Canadian Magazine called First Sailer of the Upper Lakes; A Consideration of the Question That the Wreck Found at Mississagi Straits is Indeed That of La Salle's Griffon. Without yet having visited the wreck site, Fleming tells us that: "There are many features of the wreck and its local traditions, which, when coupled with investigation and study, lead to the conclusion that the wreck is none other than the remains of La Salle's pioneer vessel wrecked in 1679, two hundred and fifty years ago."27

Fleming's article dismisses the observations of Fred Baker and Mark Dulmage, evaluates the evidence gathered by Tucker, and through acrobatics of logic, concludes that: "In all there seems to be enough evidence to indicate a very strong probability of the examined wreck at Mississagi Strait being that of La Salle's Griffon."

Fleming's article also introduces us to "Pilot Luc, an experienced Danish ship

from the original.

25 Frank A. Myers, "The Mystery of La Salle's Griffon,” Through the Years VII, 4 (February 1990), 12-18.

26 Roy F. Fleming, "First Sailer of the Upper Lakes," The Canadian Magazine 72, no. 2 (August 1929), 14-15, 44.

27

Ibid. 
captain." The source for Luc's Danish heritage is anyone's guess, as none is indicated. Fleming lists Hennepin, Joutel, Frank Severance, Francis Parkman, and Wilfred Campbell as his sources, but none of these indicate that the pilot was anything other than French. Later in the article, Fleming gives us this retelling of the skeleton story in which the skeletons are no longer Natives, but white men:

It may also be added that the investigating party learned of six skeletons of white men having been found in a cave on shore in the vicinity of the Mississagi wreck. One of the skulls was much larger than the other and would seem to correspond with that of the giant Danish pilot-Luc of the Griffon. The skeletons may not have had any relationship to the wreck at hand, yet their number and kind correspond so accurately to the known crew of the Griffon that the fact should be considered.

In 1930, Fleming made an expedition to the wreck site with two relatives to confirm his pre-determined conclusion. A notebook of his trip is conserved at Library and Archives Canada. ${ }^{28}$ The first newspaper article announcing the expedition appeared in the Toronto Daily Star with a headline proclaiming "Sunken Wreck on Manitoulin La Salle's Ship." ${ }^{29}$ Fleming dispatched articles of similar triumphant confidence to the Chicago Tribune, the Washington Post, and the New York Herald Tribune. All of the articles proclaim that "A commission of three Canadians, after a close inspection of the wrecked craft, announced today they are convinced the vessel was Le Griffon, commanded by a Danish pilot named Lucas, which was lost in a storm 251 years ago." 30

With each retelling, the story is embellished. The skeletons found in the cave, according to Fleming, "no doubt victims of the wreck"31 are cited as proof of the wreck being the Griffon. Unfortunately, all that was to be found of them in 1930 were four small fragments of bone brought to the party by a local farmer. These were presented on front page photographs as being "bones believed to be part of skeleton of Capt. Luc of the Griffon." ${ }^{32}$ The skeletons, including the legendary giant skull, had been removed from the caves over forty years earlier. This first telling of an often repeated story appeared in the New York Herald Tribune:

James Doyle of Meldrum Bay gave a most interesting description of the great skull. He stated that he placed the lower jaw bone around his own large face and that it just fitted, indicating the size of a giant. The last seen of this skull was when Harvey Balls kicked it off the lighthouse dock into the water. The investigator looked in vain in the harbor to find what might be the skull of Le Griffon's pilot,

28 Library and Archives Canada, MG30, D55, vol.8, file 69.

29 Toronto Daily Star (hereafter TDS), 25 August 1930.

30 Chicago Daily Tribune, 26 August 1930: "De La Salle's ship found wrecked 251 yrs. after storm." Washington Post, 26 August 1930: "Wreck of first ship to ply Great Lakes found in bay." New York Herald Tribune, 1 September 1930: "Searchers sure Huron wreck is La Salle's ship, Le Griffon."

31 TDS, 27 August 1930: "Say Manitoulin wreck undoubtedly La Salle's ancient trading vessel."

32 DST, 29 August 1930: "Le Griffon exploration party convinced Manitoulin wreck is that of la Salle's pioneer vessel. “ 
the giant Captain Luc. ${ }^{33}$

Within two weeks, the pilot's Danish origin was being restated by other authors as established fact; even being attributed to Hennepin as the imagined primary source:

The oldest residents of Manitoulin Island remember that in the caves near the wreck were found the skeletons of six men, one of them apparently a superhuman in size. The skull was extraordinarily large. Father Hennepin...has recorded the fact that Luc, Danish captain of the Griffin, was a man of extraordinary size. While his exact height is not known, the continual reference to his towering stature would indicate that his head must have been in proportion to the size of his body. It is not hard therefore, to imagine that the skull that a lonely lighthouse keeper tossed into the waves one dark night once encased the brains of the ill-fated ship captain. ${ }^{34}$

Soon after, in 1931, a book on the history of great lakes vessels was published by a correspondent of Fleming's. George Cuthbertson's Freshwater sealed the Danish origin of the pilot in enduring print: "Meanwhile, to add to the consternation on board, the Danish pilot, Lucas, whom La Salle suspected of treachery and being in the pay of his enemies, began to roundly berate the leader for having brought him into this danger of being drowned in freshwater, after he had braved so many perils and won such honour on the ocean." 35

After Freshwater, no major book on the history of sailing ships on the Great Lakes was written for over 75 years, and the Danish origin of Lucas the pilot became, solely by repetition, an established fact.

Fleming indicates that the only person on his expedition with any marine experience was his cousin, T. J. Batman. ${ }^{36}$ Batman is quoted as explaining the enormous size of the timbers and bolts this way: "My opinion is that it was built by early builders accustomed to build for ocean use; nothing else seems to explain the super-strength of the construction. La Salle's ship builders from France would be the justified conjecture." 37 Whether it was ever considered that the remains were of a larger vessel than the Griffon was not mentioned.

The elusive copper caulking of the Tucker expeditions turned into elusive lead caulking in the Fleming expedition. Lighthouse keeper William Grant now denied any knowledge of copper caulking and could not say where H.G. Tucker had gotten the idea. Instead, Grant now "attested" that the hull planking had been caulked entirely with lead. None of this was to be found in 1930 however, except in the recollections of Grant and

33 New York Herald Tribune, 1 September 1930.

34 Russel Gore, The Detroit News, 14 September 1930: "Mystery of first lake ship cleared."

35 George Cuthbertson, Freshwater (1931), 35.

36 TDS, 27 August 1930. Frank A. Myers, “The Mystery of La Salle's Griffon," Through the Years VII, no.4 (February 1990), 12-18.

37 Roy Fleming, The Milwaukee Journal, 2 September 1930: "Investigators Return from Lake Huron Convinced La Salle's Ship Has Been Found." 
another resident of the island. ${ }^{38}$ Many, many pages were written on the topic of this lead caulking in the succeeding decades, but the original reports indicate that not one fragment of it was ever actually seen by the original investigators. ${ }^{39}$

Great Lakes maritime historian and Toronto newspaperman C.H.J. Snider made an expedition to investigate the wreck in 1931. Snider's trip resulted in a five article series in the Toronto Telegram which examined the remains and the evidence for them being the Griffon. Snider, whose experience with wooden vessels was considerable, determined that there was no evidence to confirm that the wreck was the Griffon, though he noted that: "No greater heresy is known on this lake-girt and lake sprinkled isle... than to doubt now that this is timber from the first of all fresh water ships." ${ }^{40}$

By the 1950's, Roy Fleming himself sounded less certain of the Danish origin of the pilot. While his earlier writings suggest an established fact, in later articles he writes with an air of doubt: "Unfortunately the nationality of Moise Hillaret, the architect of the Griffon is not known. Pilot Luc is said to have been a Dane, and possibly Hillaret also came from Denmark, and had training in Danish shipyards where lead caulking had been in early use." 41

If Roy Fleming was beginning to doubt that the pilot's was a giant Dane, other writers were only just getting started with it. When another purported Griffon wreck was found on Russel Island, near Tobermory in the mid 1955, there was a Danish giant's skeleton waiting nearby:

"The bones of both left and right femur and tibia etc., obviously those of a very large man, are greater in size than those of Orrie Vail, who is over 6'2" in height. It is well known that Lucas or Luc, the Danish pilot of Griffon, who singlehanded stayed at the tiller and brought her safely through the violent blow she met when up-bound on Lake Huron, was of great size. These bones could easily be his." ${ }^{22}$

In the mass of literature that has appeared since the 1955, the identity of the pilot as a very large Dane has been consistently reaffirmed by the prominent authorities who have written on the topic. The phrase "it is well known that..." has substituted for citation of an original source.

38 Ibid.

39 Fleming's 1952 article in Inland Seas says that Tucker found lead still in the planking seams, but this is contradicted by the primary sources.

40 C.H.J. Snider, Toronto Evening Telegram, 12 August 1931: "Silver 'Turnip' Watch May be Vital Clue to Identity of Wreck." Snider's five article series appeared 11-15 August 1931.

41 Roy F. Fleming, "The Search for La Salle's Brigantine Le Griffon,” Inland Seas VIII, No. 4 (Winter 1952) and IX, no.1 (Spring 1953). Moïse Hillaret was from Saintonge, France, just south of La Rochelle. See: Joe Calnan, "Moïse Hillaret, the First Shipwright on the Great Lakes," Inland Seas LVIII, 3 (Fall 2002), 190-207.

42 Rowley W. Murphy, "The Griffon Wreckage at Tobermory,” Inland Seas XII, 4 (Fall 1955), 275-85. 


\section{Luc Dare}

When Fleming broke the story of his 1930 Manitoulin Island expedition in the Toronto Star, another article appeared close by on the front page. Dr. George Fox, an archaeologist from Michigan, was also on Manitoulin Island, leading an expedition from Chicago to excavate Native burial sites. ${ }^{43}$ Fox worked for the McDonald-Warren Foundation, funded by Zenith Radio president, Commander Eugene F. McDonald. Dr. Fox took an interest in the story of the wreck on Manitoulin Island and conveyed it to Mr. McDonald.

Fleming was issued a permit to salvage the wreck on Mississagi Strait in 1931, but before he was able to act on it, a storm swept the remains off of its limestone ledge and into the deep water of the strait. Further investigation of the wreck would now require costly diving equipment. At that time, diving equipment was only available to commercial enterprises and the very wealthy. Commander McDonald was just such a man. In 1937 he equipped his 185-foot yacht Mizpah, and set out to the Mississagi Strait with his nephew and Dr. Fox. The Associated Press article announcing the event is the first source of the pilot's new surname. It comes from an interview with Commander McDonald himself: "He said he had heard two human skulls had been found in a cave on the island. One was abnormally large, and he said Luc Dare, commander of the Griffin, was known to have had an unusually large head." ${ }^{44}$

The name Dare does not appear in subsequent articles about the McDonald expedition, nor does Dr. George Fox, who was McDonald's historical advisor, use the name in his 1955 article in The Beaver. ${ }^{45}$ The Associated Press article was run by newspapers across North America, however, and the name Luc Dare was unleashed.

The pilot's new surname soon began to turn up in other articles. An October 1937 article in the Sault Ste. Marie Evening News featuring Captain Luc Dare places the wreck in the St. Mary's River and has the Griffon bound for Montreal - which would have had the barque sailing over Niagara Falls. ${ }^{46}$ Luc Dare appears again in 1946 in an article by Richard Tappenden, a contemporary of Commander McDonald: "Young Grant, who was over six feet tall, could place the jaw bone of the skull around his own face on the outside. They didn't know that this large skeleton matched some of the descriptions of Captain Luc Dare, the huge Danish pilot of the Griffon." ${ }^{47}$

C.H.J. Snider also uses the name Dare in his 1956 article in Ontario History although only tentatively: "La Salle entrusted his present fortune - his only ship and her

43 Toronto Star, 25 August 1930: "Georgian Bay yields Treasure Trove in Centuries Old Grave of Indian."

44 Associated Press article appearing in many newspapers on 31 July 1937 including The Daily Northwestern (Oshkosh), The Daily Tribune (Wisconsin Rapids), The Bee (Danville, Virginia), The Advocate (Newark, Ohio) and The Globe (Ironwood, Michigan).

45 George R. Fox, “Was This La Salle's 'Griffin'?” The Beaver (Winter, 1955), 36-41.

46 The Evening News (Sault Ste. Marie, Michigan), 7 October 1937.

47 Tappenden, Richard, "A Possible Solution to the Mystery of the Griffin," Inland Seas II, 4 (1946), 3-6. 
cargo of furs, which represented an investment very large for the time - to Luke Dare or Dane, his Jutish sailingmaster or 'pilot' of uncharted seas." 48

In later writing about the Griffon, Snider continued to use both names: "One exception was the heretic sailing-master or "pilot, Luc or Lucas, called also Luke the Dane and Luke Dare. Instead of praying he roundly cursed La Salle for bringing him to perish in a dirty lake and so lose the glory he had acquired by long and prosperous voyaging on the oceans." ${ }^{49}$

Exploring the growth of the legend surrounding LaSalle's pilot makes an interesting study in the generation of folklore. Knowledge of the pilot in the Englishspeaking world began in 1704 with a few spare words in the English translations of Hennepin's already questionable narratives. This was supplemented in the 1800's by Francis Parkman who translated documents from the French archives for his biography of La Salle. The 1876 publication of Pierre Margry's collection of documents relating to the explorations of LaSalle and the subsequent translation of many of them added more primary-source information to the general knowledge of La Salle and his voyage. It wasn't until the 1927 expedition that asserted a wreck on Manitoulin Island's western tip was La Salle's lost vessel that the record took a turn toward the fanciful. Harry G. Tucker and Roy F. Fleming were two men with active imaginations and very close connections to the mass media. Fleming was outstanding in his ability to get his story out to a vast array of publications. By the time C.H.J. Snider or any other investigator had arrived on the scene, Tucker and Fleming's version of events had long been front page news across North America and the historical record was irreconcilably intermixed with folklore. To this was added a simple typographical error in 1937 that produced the surname "Dare" for the pilot, and by way of the Associated Press wire, the name was announced across North America. In this confused state, the historical record remains to this day. In order to move forward, let us now go back to the original documents, reevaluate what information about the pilot can be confirmed, and look for information that has been previously missed.

\section{French Primary Sources on the Pilot}

In the case of La Salle's pilot, primary sources are strangely few. Of those who personally knew the pilot, Hennepin, La Salle, and Henri de Tonti are the only ones thus far known to have left a written record of him. Hennepin we have already reviewed. This section will present the pilot as he is mentioned by the primary sources of La Salle and Tonti, as well as the Relation des Descouvertes et de Voyages du Sieur de La Salle, an official report of La Salle's activities from 1678 to 1681. This last document, as discussed by Jesuit scholar Jean Delanglez, is not actually a primary source, but was compiled from La Salle's letters by his representative in Paris, the Abbé Claude Bernou. Only one of La Salle's letters describing the construction and voyage of the Griffon has survived intact and Bernou's Relation is our only record of what the missing portions of his letters contained. Delanglez has compared Bernou's Relation to surviving fragments

48 C.H.J. Snider, "In Search of the Griffon," Ontario History XLIV, 1 ( January 1952), 31-40.

49 C.H.J. Snider, The Griffon (Toronto, 1956), 11. 
of La Salle's letters and determined that the Relation is a faithful transcription of the surviving letters and can be accepted as trustworthy evidence for the missing portions. ${ }^{50}$ Bernou's Relation gives us our earliest glimpse of the pilot, indicating that La Salle brought him from France in the summer of 1678: "The Sieur de La Salle left from France in the month of July of the year 1678 with the Sieur de Tonty, a pilot, some sailors and many others to the number of around thirty people, some anchors and rigging for the barques which he intended to have built, and the necessary arms and merchandise." ${ }^{51}$

From La Salle's trusted friend and lieutenant Henri de Tonty, we have a reliable memoir titled Relation des Entreprises de M. De La Salle, de 1678 à 1683. This memoir was signed and dated at Québec, 14 November 1684, and gives the most detailed account of the pilot's mishaps on Lake Ontario. In his Relation, Tonty identifies the ship on which La Salle and the pilot sailed from France as the Saint-Honore of 200 tons, which departed La Rochelle on 14 July $1678 .{ }^{52}$ Tonty's Relation gives the first glimpse of the pilot in action. On Christmas Eve 1678, he nearly wrecked one of La Salle's Lake Ontario barques on a shoal off present-day Prince Edward County, Ontario: "The 24th M. de La Salle having ordered his pilot to keep to the southern coast, the said pilot neglected this order during the night, and this was the cause of us thinking we would all perish on a rocky shoal, opposite the Isle of Quinté, where the Sulpician fathers have their mission. ${ }^{, 53}$

La Salle was awakened by the "extremely large waves" as the barque approached the shoal, saw the danger, and corrected the course, delivering the barque and its passengers from harm. The next day found the barque on the south coast of Lake Ontario, entering Irondequoit Bay to trade at the village of Tsonnontouan, near presentday Rochester, New York. Continuing their route to Niagara, the barque was becalmed:

50 Jean Delanglez, “A Calendar of La Salle’s Travels, 1643-1683,” Mid-America XXII (1940), 278-305, 284.

51 The document here referred to as Bernou's Relation is: "Relation des descouvertes et des voyages du sieur de La Salle, seigneur et gouverneur du fort de Frontenac, au delà des grands lacs de la Nouvelle France, faites par l'ordre de Monseigneur Colbert -1679-80-81," Pierre Margry, Découvertes et Etablissements, vol. 1: 435-544, 439. The original document is in the Bibliothèque Nationale de France, Fonds Clairambault, 1016. An English translation of this document is found in Melville B. Anderson, Relation of the Discoveries and Voyages of Cavelier de La Salle from 1679 to 1681 (Chicago, 1901). The present author has worked from the transcript in Margry for a more precise translation than that given by Anderson.

52 Relation de Henri de Tonty, entreprises de M. De La Salle, de 1678 à 1683, écrite de Québec, le 14 novembre 1684, Margry, vol. 1: 573-616, 574 (hereafter RHT ). The original document is in the Bibliothèque Nationale de France, Fonds Clairambault, 1016. Tonti's relation is available in an English translation: Relation of Henri de Tonty Concerning the Explorations of La Salle from 1678 to 1683, translated by Melville B. Anderson (Chicago, 1898). A second memoir was written by Tonty in 1690 and sent to Pontchartrain in 1693. This later document, being written many years after the event, is less clear and gives no additional information about the pilot. It appears in an English translation: Isaac J. Cox, The Journeys of La Salle (New York, 1905). RHT, 575. 
"The wind having failed us nine leagues from the said river, we took the route by land and, M. de La Salle ordered his pilot that should the wind come from the northwest, to put in to the mouth of the river, and in case of southwest, to return to the Tsonnontouans, because of the season." 54

Shortly after La Salle and Tonty departed, the pilot succeeded in wrecking the barque. Hennepin gave one version of the event, but the description in a letter by La Salle is far more detailed and trustworthy:

The autumn of '78, I lost a barque the day after I got off of it, by the fault of my pilot, who was skilled and had seven good crewmen; he having left it alone offshore and having gone to sleep on land with all his crew, such that during the night, the wind rising all off the sudden, he couldn't get back on board, and the anchor cable having slipped and run overboard, the barque was thrown on the rocks where I lost with this barque 5 or 6,000 livres, and consumed the time of ten or twelve men to transport the things which were salvaged, and to go fetch provisions for the workers, from thirty leagues away, during the entire winter, those which were in the barque having been completely lost. ${ }^{55}$

Bernou's Relation repeats the story of the wreck on Lake Ontario: "His barque, laden with provisions and with some merchandise, suffered shipwreck on the southern shore of the lake within ten leagues of Niagara, through the fault of the pilot, who, with all the sailors, left it in order to go ashore to sleep." ${ }^{, 6}$

Two weeks after the wreck of this barque, the pilot is mentioned in a letter written by La Salle to Dominique La Motte de Lucière, who briefly commanded a crew of La Salle's men at Niagara in La Salle's absence. The letter requests La Motte to send assorted provisions and supplies to various people; among them, Lucas is mentioned two times. First, La Motte is instructed to send meat to the barque if his hunter has killed any, and to write down the quantity sent so that Lucas will know if any has been eaten on the way: "Si vostre sauvage a tué de la viande ie vous prie d'en envoyer à la barque et de recommander à ceux qui la porteront de n'en pas manger et pour cela en écrire la quantité à Lucas..."

Later, La Motte is asked to send sail canvas to Lucas and give him the dimensions of some sails; adding that if the sails need to be lengthened, they will do so with bonnets ${ }^{57}$, which always work well: "Envoyes aussy à la barque la toile de voile qui est à la cabane et prenes la peine de mander à Lucas que la grande voile aurra 21 pied d'envergeur' et la mizaine seize pieds qu'il n'a qu'à les charger de cette toille et que pour

54 RHT, 576.

55 La Salle, "Lettre de découvreur à un de ses associés, 29 Sept. 1680,” Margry, II: 32-93, 67. Author's translation. Original is in the Bibliothèque Nationale de France, Fonds Clairambault, 1016, fol. 65.

56 Bernou's Relation, 23. Anderson translated barque as "vessel" the original word has been replaced for clarity.

57 Bonnets are extensions laced to the foot of a sail to increase the sail area for more power in light winds. 
les allonger on le faira par le moyen de deux bonnettes qu'on fait toujours bien." ${ }^{28}$

Of all primary sources that mention the pilot, the above letter bears the earliest date. Although it never says that Lucas is the pilot, the substance of the letter combined with Hennepin's narratives and the absence of any other Lucas in La Salle's entourage allows us to assume that Lucas is the pilot.

Once the construction of the Griffon was completed and she was launched, it was necessary to tow her up the strong current of the Niagara River to Lake Erie. The tow was especially risky because any mishap could result in the barque going over Niagara Falls. A letter written by La Salle in $168(1)^{59}$ describes the pilot's refusal to take the Griffon up the river to Lake Erie unless he was given a waiver by Henri de Tonty that would hold him blameless in the event of any unfortunate "accidents":

The pilot, either out of malice or out of ignorance, did not want to risk it in this passage without a waiver stating that he was not responsible, from M. de Tonty, who commanded my men. M. de Tonty, reflecting upon the manner in which this pilot had allowed the loss, the previous autumn, of my other barque, believed that he only made this request so that he could cause the wreck of this second one without being held culpable. He did not want to give it to him without advising me of it... I believed that it was necessary to change the decision that I had made to send M. de Tonty ahead, with my barque, and to go myself to lead it; I left immediately and, after various attempts, I surmounted the difficulties and entered the lake the $7^{\text {th }}$ of August. I perceived so much ill will and so little care in my pilot all of the time that I employed him in making these maneuvers, that I thought that I ought not entrust him with the care of this vessel in its maiden voyage, where he could have a hundred pretexts to feign innocence, if he was in the pay of my enemies, as he appeared to be. ${ }^{60}$

Upon ascending the Niagara River to Lake Erie, the barque departed immediately on 7 August for Lake Michigan. Shortly after getting underway, the pilot almost ran the Griffon aground on Long Point, which extends a third of the way across Lake Erie from the north shore:

It was night time, and a thick fog concealed the view of the land, from which we were ten leagues offshore. I heard breakers in front of us about a league away. Everyone thought that it was a certain noise typical on the lakes when the wind changes, which always comes from the direction from which the wind will come, and the pilot wanted to crowd on more sail to reach anchorage before we were taken aback by it... . Finally the fog having dissipated, my thought proved to be true, and

58 Pierre-Georges Roy, ed., Rapport de l'Archiviste de la Province de Québec pour 1927-1928 (Quebec, 1928), 320.

59 This letter is dated Fort Frontenac, August 22, 1682 in Margry,II: 212-262, but several authors, including Jean Delanglez, have pointed out that the actual date of writing is 1681 . Delanglez, 292.

60 La Salle, "Lettre de Cavelier de La Salle - Au Fort Frontenac le 22 Aoust 168(1)," Margry, II: 212-262, 214. Author's translation. The original document is in the Bibliothèque Nationale de France, Fonds Clairambault, 1016, fol.170. 
everyone recognized that they were obliged to me for having escaped this danger. ${ }^{61}$

Having survived a near disaster, the Griffon continued westward along Lake Erie to pick up Tonty and five men at the "Pointe du Détroit," located at the mouth of the St. Clair River. The barque arrived there on 10 August and continued through the strait or détroit from Lake Erie to Lake Huron. ${ }^{62}$ As Hennepin tells us, the pilot took the measurement of Lac Sainte Claire and determined that it had a circular shape. The Griffon was towed up the current of the St. Clair River to Lake Huron.

Upon reaching Lake Huron, the Griffon set off to the north, coasting along the eastern shore. By night, they traversed the lake to the northwest, crossing the mouth of Saginaw Bay. The evening of August $24^{\text {th }}$ found them among the islands off of presentday Alpena, Michigan:

The $24^{\text {th }}$ he continued to bear to the northwest until the evening, when he was becalmed among some islands where there was but a fathom and a half or two fathoms of water. He sailed with only the lower sails during a part of the night, looking for an anchorage; but finding none that was secure, and the wind beginning to blow from the west, he headed to the north to gain the open lake, where he hove to while waiting for the daylight. ${ }^{63}$ He spent the night sounding at the bow of the barque, having perceived his pilot to be extremely negligent; and he continued in this way throughout the remainder of the voyage. ${ }^{64}$

With La Salle now constantly watching over the pilot, the remainder of the voyage to Michilimakinac and then to the Island of the Pottawatomies (Washington Island) is without mishap. The pilot is not mentioned again until the fateful departure from Washington Island. This passage is the source for the crew of the Griffon being comprised of "a supercargo and five good sailors":

He resolved to send the barque back from this place because of the approach of winter, and to continue his journey by canoe; but as he had only four of them, he was obliged to leave in the barque a large quantity of merchandise and equipment and tools of all sorts, and he ordered the pilot to unlade all these things at Missilimakinak, where he would pick them up on his return. He put also all of his peltries in the barque with a supercargo and five good sailors. They had orders to sail without delay to the storehouse that he had caused to be built at the end of Lake Erie where they would leave the peltries and load a large quantity of merchandise and other things which a barque from Fort Frontenac, which would be awaiting them at Niagara, would have brought them, and that immediately after they would make a return trip to Missilimakinak, where they would find directions to the place where they would bring the barque for the winter.

61 La Salle, "Lettre de Fort Frontenac le 22 Aoust 168(1)," 230-31.

62 RHT, 579; Bernou's Relation, 445.

63 To "heave to" (mettre à la cape) is to set the sails so that the "backed" foresail pushes the vessel backwards while the mainsail pushes forwards; when in equilibrium, the vessel drifts very slowly downwind at a comfortable angle to the waves, so that the crew can rest. 
They set sail the $18^{\text {th }}$ of September with a very favourable light wind from the west. No one has since been able to learn the course they took and while there is no doubt but that they perished, it has not been possible to learn the circumstances of their shipwreck other than the following:

The barque having anchored at the north of the Lac des Illinois, the pilot, against the opinion of some savages who assured him that there was a great storm in the middle of the lake, wanted to continue his voyage without considering that the sheltered location where he was prevented him from knowing the strength of the wind. He was barely a quarter of a league from the shore when the savages saw the barque tossed in a manner so extraordinary that, unable to resist the storm even though all of the sails were lowered, a short time later they lost her from sight, and they believed that she was pushed against the shoals that are near the Isles Huronnes, where she was buried. ${ }^{65}$

According to Jean Delanglez and Pierre Margry, Bernou based the above passage on La Salle's letter of 29 September $1680 .{ }^{66}$ The original letter varies somewhat from the Bernou's version of events. La Salle's letter reveals that he learned the story from the Pottawatomies themselves:

The savages, named Pottawatomies, told me that two days after his departure from the island where I had left him, the $18^{\text {th }}$ of September 1679, this blast of wind of which I have told you being raised, the pilot who was with them moored at the north coast where they were lodged, believing the wind favorable for going to Missilimakinac, as, in effect, it was on the beam, and not feeling the violence of it because of the closeness of the land over which it came, set sail against their advice, they having assured him that there was a great storm out in the lake where the lake appeared completely white; but the pilot ignoring them, replied that his ship had no fear of the wind, set sail, and the wind that was blowing increasing greatly, they noticed that he was obliged to furl all of his sails, with the exception of the two large ones, and that, however, the barque did not do more than traverse towards the islands offshore, bars of large sandbanks which extend more than two leagues offshore. ${ }^{67}$

C.H.J. Snider, who made limited use of primary documents besides Hennepin in his writing on the story of the Griffon, came to the conclusion that La Salle had, in effect murdered the pilot and crew "by his own decision to send her back, undermanned and at the wrong time of year." 68 La Salle faced the same criticism at the time of the event. His response to the accusations appears in two of his letters. His September 1680 letter reads:

$2^{\text {nd }}$ There was lacking neither the capability of the pilot, who had had this employment in the largest vessels of Canada and the Islands, nor the sailors, nobody having the custom of putting more than six of them on a vessel of fifty tons.

$3^{\text {rd }}$ The season was not too late, navigation ordinarily continues until the end of

65 Bernou's Relation, 541.

66 Delanglez, 292. Margry,II:32.

67 La Salle, "Lettre du Découvreur à un de ses associés, 29 Septembre 1680," 73.

68 C.H.J. Snider, Tarry Breeks and Velvet Garters (Toronto, 1958), 25. 
November, and she perished around the $20^{\text {th }}$ of September. ${ }^{69}$

La Salle's August 168(1) letter maintains the same stance, but the Griffon is now ten tons smaller:

These two barques had perished in my absence, after having brought them to a safe haven and sending them back under the conduct of a good pilot, the first with eleven sailors, and the second with six, even though they were but one of twenty-six tons and the other of forty, nobody putting ever, even on the ocean, a larger crew on these sorts of vessels. $^{70}$

After innumerable setbacks, La Salle finally reached the mouth of the Mississippi by canoe in 1682, claiming Louisiana for France on 9 April. The two remaining documents that give us primary information on the pilot were written after La Salle ascended the river on the return from his expedition. One is a fragment of a letter in La Salle's handwriting, missing both the beginning and the end. Margry published it in 1877, and the Magazine of American History promptly ran an English translation in the October 1878 issue. This letter gives the first report of the Pana Native boy who described seeing a Frenchman whose description matched La Salle's pilot:

He has seen the pilot of the barque that was lost in the lac des Illinois and one of the sailors, which he described to me with details so particular that I cannot doubt it, who were taken with their four comrades in the river Mississipi, while going up toward the Nadouessiou in bark canoes; that the four others were killed and eaten, this the pilot avoided by detonating one of the grenades that they had stolen from the barque and making them understand that if life were given to him and his comrade, he would destroy with similar ones the villages of the enemies of those who had captured them. These savages brought, the following spring, the Frenchmen to the village of the Missourites, where they went to treat for peace, and the pilot detonated, at their request, a grenade, in the presence of this young Pana who was there at the time. These rogues must have taken the plan, counseled by my enemies, to sink the barque and go by the Mississipi to join du Luth, who was among the Nadouessiou, after having taken the best of the merchandise which were inside to exchange for beaver and to withdraw to the baye du Nord, among the English, if their affairs went badly. This is all the more probable as the man named La Rivière, de Tours, who deserted me to follow du Luth, was in the barque, where I had left him after having recaptured him. They could not have taken this route without having passed the house of the Jesuits of the Bay, who have always acted ignorant of it and wished... ${ }^{71}$

The latest document concerning the pilot was written shortly before La Salle departed New France for the last time. This letter gives us the only known first hand description of the pilot of the Griffon. La Salle wrote to the new Governor of New France, Joseph-Antoine Le Febvre de La Barre, from the Chicago Portage on 4 June

69 La Salle, "Lettre du Decouvreur à un de ses Associés, 29 sept 1680," 76.

70 La Salle, "Lettre de Fort Frontenac le 22 Aoust 168(1)," 228.

71 "Feuille détachée, sans commencement ni fin, de la main de La Salle," Margry, II, 196-203, 202-3. Author's translation. The original document is in the Bibliothèque Nationale de France, Fonds Clairambault, 1016, fol.188. 
1683. This is the letter mentioned earlier that was described in a footnote in Parkman's Discovery of the Great West. Parkman's brief footnote has in turn been the source of countless references by later writers, but the original letter, containing the description of the pilot, has never been consulted for published histories of La Salle's ships or published in an English translation.

The eagerness that I have noticed up to now in certain people to engage me in pursuing the Pottawatomies as if they had looted and burned the barque that was lost in this lake, has always made me believe that there was some mystery hidden underneath. I have seen no indication that the Savages could have caused this boat to

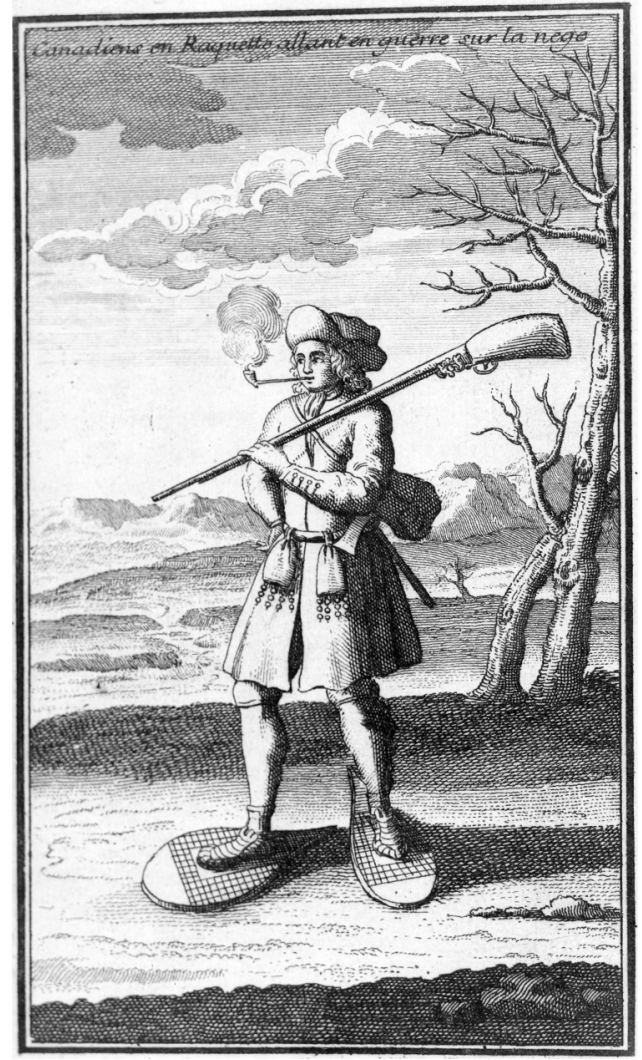

Illustration 2: A soldier of late $17^{\text {th }}$ Century New France wearing a tapabord hat, a justaucorps, culottes, or breeches and a gun in his hand. This image gives a good idea of how the pilot of La Salle's Griffon was dressed. Bacqueville de la Potherie, Histoire de l'Amerique Septentrionale. Library and Archives Canada (C-113193) perish without someone, somewhere finding some debris or seeing in their hands something with which it was loaded. I am persuaded that rather the pilot, hired by someone, would have sunk it, and then would have withdrawn himself; and I have not been able to rid myself of this thought, which has been founded upon a thousand circumstances which prevent me from doubting it. At last I hope it to soon be made clear, and it seems that God has permitted it, by this unusual conduit, to discover the wickedness of those who envy me, who would not have been able to ignore the voyage of this pilot and his comrades had they not been behind their treachery.

A young Savage of a very distant nation, of the age of fourteen or fifteen years, was given to me last year, upon the return from my discovery, by the village of Matchinkoa. ${ }^{72}$ He had been taken from the Panimaha, then from the Osages, who gave him to the Emissourites, and they in turn, to the nation from whom I received him. He followed me around a hundred leagues, and ran away one night at the entreaty of a Panneassa woman who had also been given to me. Some of my men, who were returning from hunting forty leagues from there, having found him, brought him back. He now speaks good enough French to make himself easily understood.

72 Matchinkoa was an an individual living in this village containing 600 families of Illinois 
He told us many times that he had seen two Frenchmen three years ago, prisoners of this nation, whom he describes in such a way that I cannot doubt that one of them be my pilot; that they had been captured on the Mississippi River which we call the Colbert, ascending toward the Sioux with four others in two birch bark canoes loaded with merchandise and where they had among other things some grenades of those which I had left in the barque. He told me that that the pilot, upon having detonated a grenade in the presence of these barbarians who had captured them, made them understand that with the like he would burn the village of their enemies if they would preserve his life and that of his comrade, who had not yet been eaten like the others; and also that the pilot did not yet understand at all the language of those he was with, when my young Savage saw him.

They had come in peace to the village of the Missourites where he was at the time: the pilot there detonated a similar grenade; this, the young Savage would not have been able to invent, no more than the portrait of the pilot. He also explained to me a thing that confirms his words and of which Father Zenobe will remember well, because it gave us, last year, plenty of grief.

We saw near the village of Matchinkoa a tree from which the bark had been removed three or four years ago, and on which was depicted a man with a tapabord hat pulled down below his ears, ${ }^{73}$ a grey justaucorps, ${ }^{74}$ breeches, short legs, a big beard, and agun in his hand, another figure near him, tied up like a slave, and four scalps. As we found near this tree a broad beaten path, with men's tracks and a recent fire, we believed that while the tree had lost its bark many years ago, these marks had been newly made on it.

The number of six, which corresponded with that of the men of the canoe of M. de Tonty, who was ahead, of whom I was very worried, made me believe that it was him who was depicted on this tree, even though the beard and the tapabord did not correspond, but I did not have the care to think of the pilot who always wore his

Michigamea people located on the Illinois River thirty leagues from Fort Crèvecoeur: Margry, II: 201. For more on the Pana boy, see: Mildred Wedel, "The Identity of La Salle's Pana Slave," The Plains Anthropologist XVIII, 61 (1973), 203-217.

73 A "tapabord" is a type of hat that was very commonly worn in late $17^{\text {th }}$ century New France. It originated as a mariner's hat and became popular among voyageurs, soldiers and native people. It resembled a hunting hat with a visor and ear flaps that extend all the way down the neck both in front and back. The flaps would be fastened under the chin either with buttons or ties. La Salle uses the expression "enfoncé sous le menton" or "pulled down below his chin" which was a common expression in French for a hat pulled tightly down on the head. When not in use, the flaps of a tapabord would roll up around the outside of the brim and be held in place by buttons on the visor. See: Francis Back, "S'habiller à la canadienne," CapAux-Diamants 55 (hiver, 1991), 38-41.

74 While in modern French, "justaucorps" indicates a leotard or bodysuit, a Louis XIV era justaucorps was a knee-length coat with broad sleeves, broader cuffs, and rows of buttons down the front. The justaucorps originated as a soldier's coat and became very popular in New France with the arrival of the Carignan Salières regiment in 1665. See: Francis Back, "Un justaucorps du règne de Louis XIV," Cap-Aux-Diamants 55 (automne, 1998), 54-55. 
carapousse $^{75}$ of this sort and a big beard. When I had heard reassuring news of M. de Tonty, I asked of Matchinkoa the explanation of this figure. He answered me that the children had made it from their imagination. I took this at face value at that time.

Since that time, I have concluded that they had not dared to tell us the truth of it, fearing that we would suspect them of being responsible for this murder committed by their allies. My young slave has made it clear for me, assuring me that those who captured these French had descended in a dugout canoe to this trail which is the one to their village, five days distant in the depths of the country, and that they here had made this mark, after the custom of all these people; that they had made a similar one towards Misconsing at the place where they overtook my men, and it is perhaps what one meant to say by the rumor that was spread of the death of Father Louis, Recollect, the spring of the same year, making to pass the carapousse of the pilot for the cowl of this Father, in order to make me lose the track and the thought.

I no longer doubt after all this but that it was my men, who, after having done me this cowardly act, counseled by my enemies, had believed to be able by some favors, to cover themselves by some pretext and in any case, by joining themselves to Sieur du Luth who they had gone to look for among the Sioux, to reach by way of Lake Superior the North Bay with the peltries which they had brought, and to trade the merchandise that they had pillaged from the barque.

If I did not have apprehensions that my letters would be seen by certain ones, I would tell the name of the nation where they are held captive; but as those who are either their instigators or their advisors have too much interest that this is not revealed, I would be afraid, if they had the least knowledge, that they would have their heads broken by some underground means, before I could get a hold of them, making known to these people that they are doomed if I have news of their action, this seems to me to be too great a consequence and prevents me from verifying this affair which will serve, as I hope, many others. ${ }^{76}$

Thus by la Salle's own description, the pilot of the Griffon was no giant, but a man with short legs and a large beard who wore a hat with long ear flaps, breeches and a long coat called a justaucorps.

\section{Conclusion}

Based on the primary sources, and the memoir compiled by Abbé Bernou, the pilot of La Salle's Griffon was a man who went by the names Luc and Lucas. He joined

75 La Salle here uses "carapousse" interchangably with "tapabord." A carapousse was a hat associated with mariners, pilots and fishermen that also had flaps that could roll up around the brim. In the case of the carapousse, it appears that the flaps were even more extensive than those of a tapabord, almost forming a cape on the shoulders. See: Francis Back, "Le Carapousse," Cap-Aux-Diamants 70 (été, 2002), 46.

76 Lettre de La Salle au Gouverneur La Barre, 4 Juin 1683 in Pauline Dubé, La Nouvelle France sous Joseph-Antoine Le Febvre de La Barre 1682-1685 (Québec,1993), 73-80; author's translation. This document also appears in Margry II: 325. Original Document: AN, Archives Coloniales, C13C, vol. 3, f. 44-47. 
La Salle's service in La Rochelle, France in the summer of 1678 and sailed to Quebec with La Salle on the Saint-Honore, on the $14^{\text {th }}$ of July. After traveling up the Saint Lawrence River to Fort Frontenac, Lucas began his service as a pilot of La Salle's barques on 24 December 1678. That night, he ignored La Salle's order to follow the southern shore of Lake Ontario and nearly wrecked the barque on present-day Prince Edward County. Fifteen days later, he again ignored his orders from La Salle and allowed the barque to be wrecked as it was left unattended in an exposed anchorage, losing an extremely valuable cargo. In the summer of 1679 , the pilot was suspected of intending to sabotage La Salle's new barque, the Griffon when he requested a waiver before agreeing to tow the vessel up a stretch of the Niagara River upstream from Niagara Falls. He did not receive the waiver, and La Salle came to personally lead the towing of the barque, noting that the pilot was careless and full of ill will during the process.

Upon commencing the voyage across Lake Erie, the pilot quickly showed poor judgment in wanting to press on more sail to make greater speed toward what proved to be the breaking surf on Long Point. By the time the Griffon reached Lake Huron, La Salle had so little trust in the pilot that he spent the entire remainder of the voyage checking the depth of water under the vessel with a sounding lead to be sure that the barque was not in danger of running aground. Three weeks later, almost inexplicably, La Salle sent the Griffon, loaded with merchandise, tools and equipment that were essential for his enterprise, as well as furs that were necessary for paying his debts, back to Lake Erie in the care of this pilot. The barque sailed from the Island of the Pottawatomies on 18 September 1679 and was never seen again. In the spring of 1680, Frenchmen matching the description of the pilot and one of the sailors, captives of an unidentified nation of native peoples, were seen in a village of the Missourites. There they detonated a grenade taken from the hold of the Griffon. The pilot was described by La Salle himself as a man with short legs who wore a tapabord or carapousse, a type of mariner's hat common in New France in the late $17^{\text {th }}$ century. He customarily wore a coat called a justaucorps, knee length trousers called culottes, and a big beard. Despite the lack of competence he showed during his nine months as a pilot on the Great Lakes, La Salle afterwards affirmed that he was a good and skilled pilot, indicating that he was experienced on the largest ships in Canada and the (Caribbean) Islands.

La Salle's description specifically indicates that the pilot had short legs and nothing in the primary sources points to a Danish origin of the Pilot. Unless some sound evidence comes forward to prove otherwise, the idea that the pilot was a giant of Danish origin can safely be discarded.

While the given name Lucas and its variant Luc are confirmed by the primary sources, the surname Dare appears to be nothing more than a result of misreading " $n$ " for "r" in the word Dane. The rest of the Associated Press article in which the name Dare first appears in 1937 contains several similar errors, and the name is not corroborated by any primary source. It can be safely discarded as well.

By the French customs of the time, employment and other contracts were normally drawn up by a notary who then kept the document in a register book called a 
greffe. Dozens of La Salle's contracts made in New France are preserved in the greffes des notaires held in the Québec archives. It would seem likely then, that an employment contract with Lucas would be in the archives in La Rochelle where he appears to have been hired. An inquiry into the Archives Départmentales de la Charente Maritime in La Rochelle, France, however, turned up no notarial contracts with the name Luc, Lucas, La Salle or La Motte for the year 1678.

For the Saint-Honoré, the ship on which La Salle and Lucas sailed from La Rochelle to New France, the Archives de la Charente Maritime holds a list of the names of the captain and all the crew members and their place of origin. ${ }^{77}$ Ordinarily there would also be a list of passengers' names, but this does not exist either. The crew of the Saint-Honoré included a pilot named Jacques Hurtin, but no Lucas appears on the list. The Saint-Honoré, also appearing in the records as L'Honoré, made voyages almost annually from La Rochelle to Canada and the Antilles from 1678 to $1692 .^{78}$

If any formal report was ever made of the death of the pilot and his crew to the authorities in New France, it has not surfaced. Searching in the archives of Québec and Library and Archives Canada has thus far not turned up any reference to a pilot named Luc or Lucas. La Salle suspected the Pilot's objective to have been the Lake Superior expedition led by Daniel Greysolon Dulhut (Duluth), but the latter's journal gives us no clues. Of the several Lucs and Lucases alive in New France in the late $17^{\text {th }}$ century whose names appear in the records, none has yet been found that corresponds with La Salle's pilot.

La Salle indicates in his letter to La Barre that he thought it was futile for him to attempt to locate the pilot, for as he says, those who were behind his treachery would have the pilot killed to protect their interests if they knew that La Salle was doing so. Even if he had wanted to go and look for the pilot, his plans to establish a colony on the Gulf of Mexico at the mouth Mississippi did not afford him the luxury of time to do so. Only six weeks after writing his letter to La Barre from the Chicago Portage, La Salle sailed to France from Québec in November 1683, never to return to New France. So here, it appears, the trail of La Salle's pilot ends - for now.

77 Archives Departementales de la Charente Maritime, cote B 5677, "Rôle de l'équipage et la déclaration de cargaison du navire l'Honoré pour son voyage au Canada puis aux Antilles en 1678." This document is dated 5 May 1678, more than two months before La Salle and his men sailed from La Rochelle.

78 Marcel Delafosse, "La Rochelle et le Canada au XVIIe siècle," Revue d'histoire de l'Amerique française IV, 4 (1951), 469-511. 